NBER WORKING PAPER SERIES

\title{
THE IMPACT OF EMERGING MARKET COMPETITION ON INNOVATION AND BUSINESS STRATEGY
}

\author{
Lorenz Kueng \\ Nicholas Li \\ Mu-Jeung Yang \\ Working Paper 22840 \\ http://www.nber.org/papers/w22840 \\ NATIONAL BUREAU OF ECONOMIC RESEARCH \\ 1050 Massachusetts Avenue \\ Cambridge, MA 02138 \\ November 2016
}

We received financial support from Industry Canada, which covered the cost of vetting the results of our analysis. Industry Canada was otherwise not involved in the conduct of our research. In particular, Industry Canada, Statistics Canada, nor any other party had the right to review the paper prior to its circulation. We did not receive any other financial support for this research, and we have no financial interest in its outcomes. The views expressed herein are those of the authors and do not necessarily reflect the views of the National Bureau of Economic Research.

NBER working papers are circulated for discussion and comment purposes. They have not been peer-reviewed or been subject to the review by the NBER Board of Directors that accompanies official NBER publications.

(C) 2016 by Lorenz Kueng, Nicholas Li, and Mu-Jeung Yang. All rights reserved. Short sections of text, not to exceed two paragraphs, may be quoted without explicit permission provided that full credit, including $\odot$ notice, is given to the source. 
The Impact of Emerging Market Competition on Innovation and Business Strategy

Lorenz Kueng, Nicholas Li, and Mu-Jeung Yang

NBER Working Paper No. 22840

November 2016

JEL No. F14,L2,O3

\section{ABSTRACT}

How do firms in high-income countries adjust to emerging market competition? We estimate how a representative panel of Canadian firms adjusts innovation activities, business strategies, and exit in response to large increases in Chinese imports between 1999 and 2005. On average, process innovation declines more strongly than product innovation. In addition, initially more differentiated firms that survive the increase in competition have better performance ex-post, but are ex-ante more likely to exit. Differentiation therefore does not ensure insulation against competitive shocks but instead increases risk.

Lorenz Kueng

Kellogg School of Management

Northwestern University

2001 Sheridan Road

Evanston, IL 60208

and NBER

1-kueng@kellogg.northwestern.edu

Nicholas Li

University of Toronto

150 St. George Street

Toronto, ON M5S 3G7

Canada

nick.li@utoronto.ca

\author{
Mu-Jeung Yang \\ Department of Economics \\ University of Washington \\ Savery Hall, 327 \\ Seattle, WA 98195-3330 \\ mjyang@uw.edu
}


What is the impact of trade integration with low-income countries on firm dynamics in high-income countries, including firm policies such as innovation and business strategy? A large empirical literature has documented that imports from low-wage economies such as China had a dramatic impact on manufacturing firms in high-income countries. Establishments and firms in the US and Europe have either cut jobs and lost market shares or have shut down altogether; see Bernard, Jensen and Schott (2006) and Bloom, Draca and Van Reenen (2015). These results are symptomatic of a relocation of manufacturing production from costly high-wage economies to cheaper low-wage economies and therefore reflect the static benefits for rich countries of more import competition.

However, according to traditional R\&D based models of endogenous innovation, ${ }^{1}$ there are potentially significant dynamic costs for the importing high-income country from more import competition. In these models, more competition reduces expected profits of firms in high-income countries, thereby diminishing the incentives to innovate.

In contrast, a number of recent studies have argued that product markets in rich countries are segmented and that some segments can shield firms from the adverse effects of low-cost import competition. One example is segmentation along the product space, as firms with novel products or with higher quality products might lose less market share to low-cost Chinese competitors; see Khandelwal (2010) and Sutton (2012). Another possibility is geographic segmentation, where firms that produce for local niche markets instead of mass producing for the national market are more protected against low-cost emerging market competition; see Holmes and Stevens (2014). Market segmentation along product or geographic dimensions opens up the possibility that firms in rich countries try to specialize in these differentiated or higher quality products in response to low-cost import competition from China and hence innovate more instead of less. In other words, there could be important dynamic gains for rich countries that reinforce the static gains from more import competition, as in models of Amiti and Khandelwal (2013) and Bloom, Romer, Terry and Van Reenen (2014).

In this study, we provide a comprehensive assessment of the response of firms a highincome country to import competition from China, using a nationally representative panel of firms from the Canadian manufacturing sector from 1999 to 2005. A key contribution of this paper is to investigate how firm performance and innovation responses differ as a function of initial firm characteristics that capture market segmentation along product or geographic dimensions. Our study is complementary to existing empirical work on these issues in at least three respects.

\footnotetext{
${ }^{1}$ Leading examples include Romer (1990), Grossman and Helpman (1991), Aghion and Howitt (1992), Klette and Kortum (2004), and Atkeson and Burstein (2010).
} 
First, the majority of current studies focuses on samples of very large firms, such as the publicly traded companies in Compustat. ${ }^{2}$ A common finding is that large firms in the US do systematically reduce innovation as measured by R\&D or patenting. On the one hand, this finding could reflect diminished innovation incentives as described by traditional R\&D based models of innovation. On the other hand, large firms might substitute labor-saving process innovations for production off-shoring to low-wage countries like China, as argued for example by Bena and Simintzi (2015). ${ }^{3}$ We provide a complementary perspective to these large firm studies by estimating the innovation response in a panel of Canadian firms that is representative of the entire Canadian manufacturing sector, including small and privately-owned firms. Additionally, the presence of smaller firms in our data is important as it enables us to capture the impact of competition on exit more comprehensively since small firms are more likely to exit than large firms. From this perspective, our evidence adds a better understanding of exit effects relative to studies relying on Compustat, which captures large firms that are less likely to exit in response to competitive shocks.

Second, an empirical challenge that arises in the analysis of a representative sample of firms is that traditional measures of innovation activities such as patenting or R\&D spending are typically limited to relatively large firms and exclude small and medium sized companies; see for example the evidence in Autor et al. (2016b). Our dataset has two unique features that directly address this issue. On the one hand, we measure all forms of innovation, including investments in novel business processes protected by trade secrets or incremental product innovations. ${ }^{4}$ On the other hand, the dataset provides selfreported measures of intended business strategies, which allows us to measure whether firms have innovation or low-cost production as their top strategic priority; see Yang, Kueng and Hong (2015) for more details. Our measures of intended strategies have the additional advantage that they are not outcome variables such as patenting and therefore allow an analysis free of hindsight bias, which would confound the effects of luck with the effects of intended firm policies and would therefore potentially ignore the risks associated with innovation activities. Moreover these business strategy and innovation measures are available for all firms and therefore allow us to contrast the impact of Chinese competition

\footnotetext{
${ }^{2}$ See e.g., Autor, Dorn, Hanson, Pisano and Shu (2016b) or Hombert and Matray (2014).

${ }^{3}$ Note that this off-shoring mechanism has very different implications for innovation of rich country firms, as flow profits of firms that benefit from outsourcing would increase, thereby increasing innovation incentives.

${ }^{4}$ Another advantage of using survey data on innovation rather than patenting data is the increasing popularity of patenting as a strategic tool by incumbents vs. entrants (Boldrin and Levine (2013)) as well as a rent extraction tool by patent trolls (Tucker (2014)). From this perspective a fall in patenting in response to more competition from China might just reflect the fact that domestic firms in high-income countries recognize that they cannot enforce domestic patents against Chinese competitors and therefore reduce patent applications.
} 
on strategy and innovation decisions as a function of initial firm heterogeneity, such as for small vs. large firms.

Third, because detailed data on the geographical scope of firms is scarce, most existing studies of the impact of low-wage import competition on innovation typically ignore whether a given firm produces for the national market or a local niche market only. Yet, as Holmes and Stevens (2014) show, local niche manufacturers in the US have been systematically less affected by Chinese import competition. We provide a unified empirical perspective of firms' innovation and business strategy responses as a function of initial size, initial strategy and initial geographic scope.

Our identification strategy mirrors the empirical approach by Autor, Dorn and Hanson (2013) who utilize the massive expansion of Chinese exports in the wake of China's WTO accession as a natural experiment. Similar to Bernard et al. (2006) for the US and Bloom et al. (2015) for Europe, we find that increased import competition from China led Canadian manufacturing firms to strongly contract in terms of market share and employment and significantly increase the likelihood of exit. In terms of firm policy responses, we find that Canadian manufacturing firms systematically reduced innovations in response to increased import competition from China, consistent with the results of Autor et al. (2016b) for large U.S. firms. Furthermore, this reduction in innovative activity is strongly driven by a drop in process innovation rather than product innovation, similar to the findings by Bena and Simintzi (2015).

However, these pooled results mask very different responses for firms with different initial characteristics, which we define as firm characteristics in the years before China joins the WTO. We emphasize three sets of results in particular. First, initial size is important to gauge whether the average drop in process innovation could indeed be driven by off-shoring, as large firms are more likely to off-shore to low-wage economies than smaller firms. In this context, we find that the drop in process innovation is indeed stronger for small firms. At the same time, small surviving firms in Canada seemed to have systematically shifted away from low-cost as their top strategic priority in response to Chinese import competition. These responses are consistent with small firms utilizing cost-saving process innovations if they compete on low costs, but do not pursue such process innovations if they shift away from low cost as their top strategic priority. In complementary work, Yang et al. (2015) show that firms with low cost as their top strategic priority indeed systematically pursue process innovations.

Our second set of results focuses on differential firm responses as a function of initial business strategy. We find that firms stating innovation as their top strategic priority in the years before China joins the WTO grow larger if they survive. However, we also 
find that firms with initial innovation strategies are more likely to exit in response to import competition from China. These results suggest that low-wage competition renders innovation strategies more risky, a finding that can potentially be explained by a model in which most innovating firms focus on narrow product lines that risk becoming unprofitable as Chinese low-cost competitors enter; see e.g., Fernandes and Paunov (2015).

Our third set of results utilizes our detailed geographic data to investigate whether a very narrow geographic scope shields Canadian manufacturing firms from Chinese competition. We find a risk increases similar to the effects of innovation strategy. In particular, firms specializing in selling to local markets - defined as the municipality or county of the firm's location - are more likely to exit in response to Chinese competition. At the same time, if these local firms survive, they are systematically less affected in terms of market share losses than firms that earn most of their revenues the national Canadian market.

The remainder of the paper is organized as follows. Section 1 discusses the data utilized throughout the paper and the methodology to identify the causal effect of increases in Chinese import competition on various outcomes for Canadian firms. Section 2 lays out our empirical results and section 3 provides additional robustness checks. Section 4 concludes.

\section{Data and Methodology}

\subsection{Data}

Our confidential firm-level data come from Canada's Workplace and Employment Survey (WES), a random stratified sample conducted by Statistics Canada with the universe of Canadian firms as the sampling frame. ${ }^{5}$ The survey is stratified by (NAICS 4-digit) industry, firm size and region, and we use the population weights provided for all summary statistics and regressions. Firm size classes are based on employment bins and throughout the paper we use the WES classification of "small" (between 1 and 19 employees), "medium" (between 20 and 499 employees) and "large" (500 or more employees). We use data from the 1999, 2001, 2003, and 2005 waves of the survey. ${ }^{6}$ The data is a panel with re-sampling due to firm exit or attrition. We restrict our attention to manufacturing firms (NAICS industry codes with 3 as the first digit) since Chinese exports are heavily concentrated in manufacturing with an export share of more than $80 \%$ over our sample periods; see Autor, Dorn and Hanson (2016a). This gives us a starting sample of 1370

\footnotetext{
5 See http://www23.statcan.gc.ca/imdb/p2SV.pl?Function=getSurvey\&SDDS=2615 for the WES questionnaire. The online appendix reprints sections $\mathrm{G}$ and $\mathrm{H}$ of the survey for convenience.

${ }^{6}$ The survey is conducted every year from 1999 to 2006. Information about business strategies is asked every other year.
} 
firms, of which about 900 survive until the end of the period depending on which outcomes we examine.

A unique aspect of the WES data is that it contains detailed measures of firms' (exante) intended strategies to deal with increased competition as well as firm (ex-post) outcomes, such as innovation and current performance. Table 1 presents summary statistics for our main variables, which we now describe in detail. Note that the sample contains a good mix of small, medium and large firms although the latter two classes are significantly over-sampled on purpose and make up a much smaller share of the total firm population.

Firm business strategies are measured in Section G of the WES. Firms are asked to rate the importance of 15 different strategies on a five point scale from "Not important" to "Crucial," with strategies ranging from expansion to new markets, new products, quality management, and cost reductions. We focus on two sets of strategies that prove contrasting but plausible responses to low-cost import competition, innovation strategy and low-cost strategy. Innovation strategy corresponds to three specific questions: "Undertaking research and development," "Developing new products/services," and "Developing new production/operating techniques." Low-cost strategy corresponds to two different questions: "Reducing labour costs" and "Reducing other operating costs."

An important measurement issue we face is that respondents are asked to assign a numerical value from 1 to 5 to the importance of factors like "improving quality" or "lowering cost", with higher values reflecting higher strategic importance. These numerical values by themselves seem problematic, especially when comparing responses across respondents. Specifically, it seems that some respondents systematically rate all strategic factors higher on average, considering more or less everything as important, while others rate all factors particularly low. These difference reference points make a direct comparison of numerical Likert-scores across respondents and therefore across firms potentially problematic. To deal with this issue we construct two different strategy measures, which capture the essence of the specific research questions we aim to answer.

First, for cross-firm comparisons, such as differences in the competitive response as function of initial strategy, we construct top strategic priorities. These are defined as indicator variables equal to one if the firm considers the factors to be more or at least equally important to any other strategic factors listed. We also require a strategic factor to be considered at least "important" (a score of 3) to be considered a strategic priority. This strategic priority variable has the advantage that it extracts mostly ordinal information on the strategic priorities of the firm and therefore avoids the comparison of mean responses across respondents. We use it especially for comparing differential responses to Chinese 
competition across firms, as a function of these priorities.

Second, we also construct a more continuous measure for the purpose of analyzing within-firm changes in strategies as a response to the increase in emerging market competition. Our rationale is that when we ask "How much did the importance of this strategy change over time?", we ideally want to rely on within-firm variation. However, even when only using within-firm variation, there remains an issue if survey respondents change over time within the same firm. To deal with this issue we adjust these measures of strategic changes by subtracting the average importance of the relevant strategy questions relative to other strategic factors. Specifically, we first subtract the mean importance score of all 15 strategy questions for each firm (thereby normalizing the importance of a particular strategy relative to the others within a firm) and then average across the relevant questions for innovation or low-cost strategy listed above.

Table 1, panel A, reveals that innovation strategies are relatively rare in Canadian manufacturing in 1999 - only about $7 \%$ of firms rate it as a top priority (about 9\% of our unweighted sample which over-represents larger firms). Low cost strategies are more common, as about $18 \%$ of firms list this as a top priority. Table 1, panel B, indicates that among the firms that survived from 1999 to 2005, there has been a much greater increase in the relative importance of low cost strategies (an increase of 20 percentage points (pp)) than innovation strategies (an increase of $8 \mathrm{pp}$ ) although both roughly doubled relative to their baseline in 1999 and both gained in importance relative to other strategies.

Section $\mathrm{G}$ of the WES also contains several questions measuring perceptions of competition. Firms are asked "to what extent do these firms offer significant competition to your business" and respond based on a similar five point importance scale (with "don't know" as an additional category), with separate items for locally-owned firms, Canadian-owned firms, US-owned firms, and Other internationally-owned firms. This allows us assess the increase in Chinese import competition we measure in the data is actually salient to Canadian firms, something that is typically taken for granted. We measure changes in the perception of foreign (non-US) competition by taking the perceived importance of competition from "Other internationally-owned" firms and subtracting the mean importance of competition from all four sources (local, Canadian, US, non-US foreign), which like before normalizes our measure to capture changes in the relative importance of competition from this source within a firm. We construct a similar measure of perceived competition from U.S.-owned firms, which we will use as a placebo for testing our "objective" measure that uses actual Chinese import competition. ${ }^{7}$ As revealed in Table 1 Panel B, among firms

\footnotetext{
${ }^{7}$ We recognize that this is not a perfect placebo since Chinese competition could also affect competition from U.S. firms. However, we would expect this indirect effect to be much smaller than the direct effect of Chinese imports to Canada.
} 
that survived from 1999-2005 the increase in perceived importance of competition from "Other internationally-owned" firms was over three times as large as for US firms (16\% vs. $5 \%$ ).

The WES asks detailed questions about innovation outcomes and technology expenditures. Section $\mathrm{H}$ asks whether the firm introduced new or improved products during the previous year and whether it introduced new or improved processes. Based on the response, we construct distinct measures of product versus process innovation for each firm by taking the cumulative number of years the firm innovated over the period we examine (1999-2005 for our main analysis, two-year periods for our robustness check). Note that the average firm in our data innovates quite frequently based on this variable. Table 1 reveals that for the average firm that survived the seven-year period from 1999 to 2005 there were 4.4 years involving some product innovation and 3.9 years involving some process innovation. One reason innovation is so high in our data is that product and process innovation need not correspond to a patent or world-first innovation. The survey explicitly recognizes that an innovation could be a world-first but could also be a Canada first or a local market first which may simply involve adoption of existing ideas and technologies. Although the mean innovation is high, the standard deviation is also high, consistent with a wide variance of innovation outcomes across firms. Section I asks about the firm's technology use, classified as computers, computer-controlled/computer-assisted technology (e.g. robotics, optical or laser technology) and other major implementations of technologies or machineries. Our measure of technology adoption is simply the total estimated cost of adopting any of these new technologies cumulated over the relevant period, normalized by initial revenue in 1999. The average surviving firm in our data spent resources equivalent to $8.4 \%$ of its 1999 revenue on technology adoption over the 1999-2005 period.

The WES also provides detailed data on the geographic scope of each firm's market based on the percentage of total firm revenues that accrue from the local market, national Canadian market, US market, and international non-US market. Local markets are defined as counties or municipalities in which the firms are located. We use these measures to classify firms into three types - "local" firms are those that only sell to the local market, "national" firms also sell to the Canadian market but do not export, and "exporters" are firms that also sell goods outside of Canada. Based on this classification, approximately $40 \%$ of Canadian manufacturing firms export, $60 \%$ sell in the domestic market only, with $40 \%$ having very localized sales.

Finally, the WES contains several variables that can be used to assess firm performance. Although the WES does not contain the capital or input data we would need to 
estimate productivity, firms are asked to report their revenues, total employment, gross payroll, and operating profits (defined as revenues minus operating expenses) from the previous year. We use and report these variables in log changes except for profits (due to negative values), for which we calculate the change in operating profits normalized by initial revenues, i.e., the operating profit margin. The average Canadian manufacturing firm that survives from 1999 to 2005 sees substantial growth of revenue, payroll and profits over the period (from 15-25\% total over a seven-year period) but very low employment growth (under $4 \%$ over a seven-year period).

\subsection{Identification}

Our main objective is to estimate the causal effect of increases in Chinese import competition on various outcomes for Canadian firms. We measure the strength of Chinese import competition using the share of Chinese imports over total imports within a 4-digit NAICS industry. Between 1999 and 2005 the average 4-digit NAICS manufacturing sector experienced a rise in Chinese import share from $2.8 \%$ to $7.4 \%$, but for some industries the increase was much larger. Figure 1 plots the initial share of Chinese imports in 1999 for each of the 85 4-digit NAICS industries against the subsequent change, revealing a wide dispersion across industries that serves as our main source of identifying variation. For instance, China's contribution to Canadian imports in 1999 was particularly high in "apparel accessories" and "footwear" with shares of about 25\%. Accordingly, in the six-year period from 1999 to 2005 in which China's exports increased dramatically, these shares increased by another 13-15\%. On the other hand, industries like "dairy" or "printing" had low Chinese import shares in 1999 and also experienced only modest increases over the subsequent six years.

Our estimation strategy is based on using cross-industry differences in the change in Chinese import shares to identify the effects of competition on Canadian firms, where we include firm and time fixed effects. That is, we estimate specifications like equation (1):

$$
\Delta y_{i, s}=\alpha+\beta \cdot \Delta \text { Competition }_{s}+\epsilon_{i, s},
$$

where $y$ is the firm-level outcome of interest and Competition s $_{s}$ is the increase in the Chinese import share in industry $s$. Given the short nature of our panel and the potentially delayed response of firm variables - particularly business strategies and innovation - to changes in Chinese import competition, our main specification uses a long-differenced version of equation (1) where we take differences from 1999 to 2005 within each firm for the set of firms that survive throughout the period. In section 3 we show that our main 
results are robust to using two-year differences instead. For regressions where firm exit is the outcome of interest, we simply use a dummy variable equal to one for firms that exited by 2005 and zero otherwise.

One potential concern about estimating equation (1) by OLS is that the changes in Chinese import share that we observe are correlated with industry-level Canadian demand shocks or industry-level Canadian technology/supply-side shocks. For instance, Canadian demand for textiles might have increased in this seven-year period, which could have led to an increase in China's import share in this industry. Alternatively, suppose better value-chain management by Canadian firms makes it less costly to off-shore production to China. This better technology makes textiles cheaper and hence increases sales. At the same time, it also makes off-shoring to China more likely and thus increases import shipments of textiles from China to Canada.

Our use of Chinese import share relative to other importers (similar to Bloom et al. (2015)) mitigates this concern as we are essentially using China's growing competitiveness against other major exporters rather than Canada. However, there could still be demand shocks for Chinese goods or technology/supply-side shocks that are correlated between Canada and other advanced economies that export to Canada. Our main solution for this problem is to use the initial Chinese share of imports in 1999 as an instrument for future Chinese import growth at the industry level, following Bloom et al. (2015). The idea behind the IV strategy is that WTO accession and productivity growth in China during this period led to growing competitiveness of Chinese goods in industries in which China already held a comparative advantage. Figure 1, which plots the growth of Chinese import shares against the initial Chinese import share for each NAICS 4-digit industry, shows that this correlation is fairly high, and we generally find F-statistics above 10 in the first-stage of our instrumental variable regressions. We provide further reassurance that our main results are not driven by industry time-trends (in either supply or demand) in the robustness section where we use multiple two-year differences and industry fixed effects in conjunction with this IV strategy.

\section{Results}

In this section we discuss the results obtained from the analysis described in the previous section. We start by reporting the effect of increased Chinese competition from 1999 to 2005 on the average Canadian manufacturing firm. We then leverage the representativeness of our sample to study how the effect of Chinese competition varies across firms, based in their initial characteristics. 


\subsection{Average Effects of Chinese Import Competition on Surviving Firms}

Table 2 presents the average effect of Chinese import competition in a sector on firm performance outcomes based on equation (1) estimated in long-differences (1999-2005). Standard errors are clustered by NAICS 4-digit industries throughout. While the IV specifications are consistent with generally negative effects of rising import competition on the revenues, employment and profits of surviving firms, the standard errors are too large to reject a zero effect. This may be partly due to lack of statistical power but also due to selection effects on the worst performing firms. Survivors might be the best performing firms which would lead to an upward bias that could partially offset the negative effect of increased Chinese import competition. Indeed, we find large negative effects on firm exit that are statistically significant in our IV specification. The coefficient implies that the 4 percentage point increase in Chinese import share between 1999-2005 led to the exit of $3.4 \%$ of the firms sampled in 1999 over that period, which is very large relative to the $17 \%$ overall exit rate of these firms.

When firms face increased foreign competition, how do they react strategically? Table 3 presents the results for low-cost strategies and innovation strategies for firms that survive until 2005. It is useful to point out that our summary statistics on the strategic changes in Table 1 suggested that firms on average placed more priorities on the two strategies of innovation and low-cost. However, as the OLS results in Table 3 show, these aggregate changes are not necessarily driven by changes in Chinese import competition. While it is true that more firms pursued an innovation strategy in sectors that saw increased import competition from China, the same is not true for low-cost strategies. Here, we find that stronger import competition from China is correlated with firms shifting away from lowcost as their top strategic priority. At first sight, these correlations seem consistent with the notion that firms with low-cost strategies offer products that are closer substitutes to products offered by Chinese producers. These correlations are also consistent with theories in which firms pursue product differentiation to shield themselves against lowcost competition from China, as in Amiti and Khandelwal (2013). On the other hand, it is important to re-emphasize that there are potentially important reasons the correlations might not actually reflect these types of competitive effects. As previously discussed, it is possible that sectoral technology shocks might drive these correlations. An example for a sectoral technology shock that might drive these correlations is increased efficiency in supply chain management, which allows companies to more easily offshore production to China. As a result, companies might have focused more on product design and product 
innovation rather than adopting cost-saving process innovations, therefore shifting their strategic priority from low-cost to innovation. This example could therefore explain not just the strategic shift from low cost to innovation strategies but also increased import volumes from China, as companies get more intermediate products from there.

Our IV strategy of exploiting initial comparative advantage patterns helps to explicitly address this concern. As shown in Table 3, the IV results do indeed substantially differ from the simple OLS results, reinforcing the notion that sectoral technology shocks are an important omitted variable. In fact, the IV results suggest that the response to more import competition from China, firms on average do shift away from both low-cost and innovation strategies, although the impact is not statistically significant for the sample of surviving firms.

We next turn to the innovation outcomes in response to Chinese competition. We are particularly interested in the different responses to competition, depending on whether the innovation type is a process or a product innovation. To put our analysis into perspective, it is helpful to clarify what specifically differentiates these two types of innovations. Product innovations describe novel products or incremental product improvements that increase buyer utility. Examples for such product innovations include improved userfriendliness of software or new products such as a new generation of mobile devices. In contrast, process innovations describe improvements in a firm's operations of manufacturing, delivery or support services, which leave the nature of the product relatively unaffected. Examples include automation of a production process, implementation of justin-time inventory techniques, bar-coded tracking of goods, or implementation of enterprise resource software for internal accounting. Another example is the implementation of the new waste-minimizing cutting scheme for soccer balls used by Atkin, Chaudhry, Chaudry, Khandelwal and Verhoogen (2015) in their analysis of technology adoption in Pakistani soccer ball producers. What these examples have in common is that the actual product is not changed, while the process improvement often results in waste minimization and cost reduction. This view is consistent with the interpretation by Bena and Simintzi (2015), who interpret process innovations as primarily reducing labor costs. Furthermore, in complementary work, Yang et al. (2015) show that firms pursuing low-cost as top strategic priority are indeed more likely to implement incremental process innovations.

With this difference between product and process innovations in mind, it seems natural that increased competition from a low-cost country such as China might have different effects on the incentives to pursue product as compared to process innovation. In particular, in the spirit of Khandelwal (2010) and Sutton (2012), firms with novel products or with higher quality products might lose less market share to low-cost Chinese competi- 
tors which might imply that innovation incentives are not strongly affected. In contrast, if firms utilize process innovations to generate cost advantages, as is consistent with the evidence in Yang et al. (2015), then more Chinese competition might reduce the returns to process innovations very strongly. As a consequence, one would expect that incentives to pursue process innovations are drastically reduced.

We do indeed find evidence that the innovation response of firms to Chinese competition depends on the type of innovation as can be seen in Table 4. On the one hand, there are very strong and robust negative effects of Chinese import competition on process innovation of surviving firms. The average surviving firm innovated in almost 4 out of the 7 years between 1999 and 2005, but the average effect of Chinese import competition lowers this by about 0.6 years. On the other hand, we find a much weaker effect of Chinese import competition on product innovation, where the Chinese import coefficient is not significant in the IV specification (and only marginally in the OLS) and the magnitude of the effect is only about a tenth of the size for product innovation as compared to process innovation.

We also find smaller and statistically insignificant negative effects on technology ex-

penditures. At first, these results seem somewhat different from the technology adoption choices of European companies found in Bloom et al. (2015), who reported that IT spending per employee increased in response to Chinese import competition. However, it is important to note that our measures of technology are more comprehensive than measures used by Bloom et al. (2015), since they include not just IT spending but also any spending on new technologies other than IT.

Overall, our results support theories in which process innovations are complementary with market size and hence tend to decrease as competition rises, while product innovations that potentially allow firms to escape from competition with low-wage competitors are less strongly affected.

\subsection{Heterogeneity of effects by initial firm characteristics}

While the specification in equation (1) above captures the average effects of industrylevel competition from Chinese imports on continuing firms, we are particularly interested in the heterogeneity of these competition effects across different types of firms. To measure this heterogeneity we interact our competition measure with several dimensions of firm heterogeneity measured at baseline in 1999 using the following specification (2):

$$
\Delta y_{i, s}=\alpha+\beta \cdot \text { Competition }_{s}+\gamma \cdot Z_{i, 1999}+\eta \cdot \Delta \text { Competition }_{s} \times Z_{i, 1999}+\epsilon_{i, s} .
$$


The main sources of heterogeneity $Z$ we consider are motivated by the prior theoretical and empirical literature, namely size, business strategy, and geographic concentration of sales.

\subsubsection{Initial size}

Models of competition with firm heterogeneity and entry/exit, such as Melitz (2003) predict that an increase in competition will lead to the exit of the least productive firms, which are also typically the smallest. At the same time, the baseline Melitz model does not feature differences in product quality so that percentage revenue losses from Chinese competition for small firms should not differ much from percentage revenues losses for large firms.

Beyond the consideration of these basic extensive and intensive margin effects of Chinese import competition, we are also interested in treatment effects by initial firm size to understand potential mechanisms through which Chinese import competition affects firm dynamics. We documented in section 2.1 that on average, process innovation at Canadian companies significantly fell, while there was no significant effect of Chinese import competition on business strategy. One possible explanation for these findings could be along the lines of Bena and Simintzi (2015), who find that more offshoring to China is correlated with a fall in process innovation patents at large, publicly traded US companies. As a result, our aggregate findings in section 2.1, might reflect the fact that large companies use offshoring instead of process innovation to pursue low-cost strategies and are therefore less likely to change their business strategy away from low cost. In this context, initial size is a particularly useful dimension of heterogeneity, as offshoring is likely to be primarily pursued by large companies with global value chains.

Table 5 documents the responses to Chinese import competition as a function of initial firm size. Note that we treat small firms (1-19 employees) as the omitted category and include interactions of our competition measure with dummies for medium and large size firms. Starting with firm exit, our baseline IV estimates show that more import competition from China significantly increased exit of small firms, consistent with the predictions of a basic Melitz model. Additionally, note that the interaction effects for medium and large firms are negative and the combined effect of Chinese import competition on exit for larger firms is close to zero (and not statistically different than zero).

Column 2 of Table 5 moves to the analysis of intensive margin effects for the sample of firms that survive from 1999 to 2005. We find that, conditional on survival, firm revenue is not affected differently across size classes. This again is consistent with a baseline Melitz model of monopolistic competition with productivity heterogeneity across producers. 
The next columns of Table 5 allow us to focus in on the mechanisms driving our process innovation and business strategy results. In particular, column 3 shows that the negative response of process innovation to Chinese import competition is mainly driven by the smallest firms in our sample. As a result, using offshoring to China as substitute for cost-saving process innovations seems unlikely to explain our aggregate results. This is especially the case, as the interaction effect on the largest firms is positive, even if it is not statistically significant. This conclusion is further reinforced by our finding that the reductions in process innovation are less pronounced among very large firms, the very firms that are most likely to be able to benefit from production offshoring to China.

The last two columns of Table 5 illustrate that there are important differences in the strategic response to Chinese competition for small vs. large firms. Conditional on survival, large and medium-sized firms are more likely to switch towards low cost strategies, which would be consistent with greater potential for reducing employment or eliminating less profitable product lines and activities for these types of firms. In contrast, smaller surviving firms are less likely to prioritize cost reduction as a result of more Chinese competition. This is consistent with a model in which small firms are only able to survive if they systematically switch away from low-cost as strategic priority. Taken together, the responses by firm size are consistent with the view that Chinese competition affected producers competing on low-cost particularly hard in contrast to average responses in section 2.1. These insignificant results for shifts away from low-cost strategy in section 2.1 could be driven by the fact that small surviving firms had to systematically shift away from low-cost, while large surviving firms had more potential for cost-cutting and therefore shifted towards low-cost as strategic priority. Finally, regarding innovation strategies, we did not find any average increase in the importance of this business strategy, and do not find statistically different results across firms of different size.

\subsubsection{Initial business strategy}

In this section we explore the question of whether firms were affected differently as a function of their initial business strategy. This question is of special relevance in the light of prior studies by Amiti and Khandelwal (2013) and Bloom et al. (2015), which suggest that firms pursing higher quality products or deploying more advanced technologies are more insulated from the adverse effects of Chinese competition. This seems to suggest that firms in advanced economies such as Canada should pursue innovation to shield themselves against competition from low-wage countries such as China. It is worth emphasizing at this point that a particularly attractive feature of our empirical analysis is the use of measures of initially intended business strategies. The reason is that these initially 
intended strategies are not outcome measures such as patent applications and technology adoption and therefore avoid hindsight bias: a company that was lucky enough to be granted a patent before the rise of Chinese competition will outperform others due to the direct effect of patent monopoly rights as opposed to product or process innovations pursued. ${ }^{8}$

Therefore, the key question is whether firms that initially pursue innovation as their top strategic priority are performing better in response to increased Chinese competition than firms not pursuing this strategy. Additionally, our strategy measures also enable us to analyze the flip side of this question. Do firms that pursue low-cost as their top strategic priority initially tend to underperform other firms when Chinese import competition increases? Low-cost firms might be harder hit if we think their products are less differentiated than those of Chinese firms and import competition from China undermines their main source of appeal, whereas innovative firms might be less affected.

Turning to our results, Table 6 examines whether firms that had different strategic priorities in 1999 had different responses to rising Chinese imports over the 1999-2005 period. We document interactions of Chinese import competition with dummies for firms that made innovation a top priority ( $8 \%$ of the initial sample) or that made low costs a top priority (20\% of the initial sample). The first three columns of Table 6 display the effect of Chinese competition on exit as well as revenue and payroll conditional on survival, as a function of whether firms initially pursued innovation as top strategic priority. The surprising result is that exit probabilities sharply increase for firms pursing innovation strategies. The magnitudes are large and imply that firms initially pursuing an innovation strategy are four times more likely to exit in response to increase Chinese competition than firms that do not pursue such as strategy (a coefficient of 2.8 as opposed to 0.7 ). This finding might be considered unusual in the context of other empirical and theoretical studies, which suggest that higher product quality or better technology helps companies mitigate the impact of competition from low-wage emerging markets such as China. However, our results can be reconciled with such findings if one focuses on the effects of Chinese competition on the sample of surviving firms. As reported in columns two and three of Table 6 , it seems that conditional on survival, firms with innovation strategies do significantly better than firms without innovation strategies. As the results show, surviving firms with innovation strategies increase their revenue on average while reducing their payroll costs. In other words, gross profits defined as revenues minus payroll costs, are increasing. Although more Chinese competition makes exit for firms with

\footnotetext{
8 This point applies even if patent applications are used instead of granted patents. In this case, it is the luck related to finding a patentable technology as opposed to a non-patentable technology that is the omitted outcome that is directly correlated with firm performance.
} 
innovation strategies more likely, revenue and profits are also more likely to increase, conditional on survival. Seen together, these results suggest that innovation strategies do not just deterministically insulate firms from Chinese competition. Instead, innovation strategies seem to imply higher risk: they increase the probability of failure, but also systematically promise higher profits if the company survives.

Contrasting the results of innovation strategies with low-cost strategies is particularly instructive, as the last three columns of Table 6 show. Although the likelihood of exit seems to increase for firms initially pursing low-cost strategies, the extent of the increase is smaller and statistically insignificant. Furthermore, there are important differences for the sample of low-cost firms that survives. Like the firms pursuing an innovation strategy, low-cost firms do exhibit some increases in revenues, if anything. However, a big difference compared to innovation firms is that low-cost firms also see an increase in overall payroll costs. As a consequence, average gross profits appear to fall for low-cost firms. The increase in payroll costs indicated that surviving low-cost firms do not necessarily become smaller in response to more Chinese competition. On the contrary, these results are consistent with the view that surviving low-cost firms meet Chinese competition by aggressively reducing margins and striving for higher volumes. Contrasting the competitive responses of low-cost strategy firms to firms pursuing an innovations strategy we note that performance results for low-cost strategy firms seem more uniformly negative. Even as increased exit probabilities are marginally insignificant, even for surviving lowcost companies, gross profits seem to fall, in contrast to increasing gross profits for firms with innovation strategies. Indeed, while the empirical evidence for innovation strategies points to higher risks for these firms, the evidence for low-cost companies is reminiscent of more classical notions that more competition is depressing profits margins, as in the literature on pro-competitive effects of trade such as Melitz and Ottaviano (2008), Arkolakis, Costinot, Donaldson and Rodríguez-Clare (2015) and Feenstra and Weinstein (2010).

\subsubsection{Initial geographic scope}

While much of the empirical analysis in the previous subsections was focused on how differentiation along the product space might mitigate the impact of Chinese competition, in this section we pursue a complementary margin. Specifically, previous empirical research by Holmes and Stevens (2014) has identified the possibility that firms that specialize in local niche production might be less affected by Chinese import competition than firms that produce for the mass market at greater scale. As previously mentioned, a particularly attractive feature of our data is that it provides a breakdown of revenues by market, which might be local county or municipality, national market or export markets. 
While exporting and focus on local markets are obviously correlated with firm size, there is also plenty of overlap across categories, with small exporters as well as large firms that do not export. Following the geographic market segmentation model of Holmes and Stevens (2014), one would expect that firms focusing on local niche markets are less affected by Chinese competition. This should show up in lower revenue losses in response to Chinese competition as well as in lower exit probabilities for local niche market firms.

Table 7 explores the heterogeneous effects of competition for firms that focus on the local or national markets versus those that export. Note that firms initially drawing all their revenues from local counties or municipalities are the omitted baseline category. Perhaps surprisingly in light of our earlier discussion, we find that firms that sell only to local markets are more likely to exit due to foreign competition while this effect appears to be muted for firms that sell nationally or export.

On the other hand, the effects on revenue are consistent with more negative effects for surviving firms that export or sell to national markets, as documented in columns two and three of Table 7. Indeed, firms that only sell locally appear to face no change in revenues, while exporting firms see a significant drop in their revenues. Note that payroll at nationally competing firms or exporters contracts in a fashion similar to the revenue contraction. This is consistent with the view that conditional on survival, firms with broad geographic scope are losing market share and contract more relative to local niche market firms.

Taken together, these exit and intensive margin results are reminiscent of the higher risk mechanism we emphasized for innovation strategy firms in the last section. Firms focusing on local niche markets face a higher risk of exit in response to Chinese competition, but if they survive, the adverse effects of Chinese are strongly attenuated. In this respect, the pursuit of geographic differentiation seems to be similar to the pursuit of differentiation along the product space dimension.

\section{Robustness}

Our empirical approach has been widely employed in the literature, but there is a concern that increases in Chinese import competition (in changes or initial levels) are correlated with industry time-trends in technology or demand for Chinese products. Although our data only cover a short period, by constructing a panel with up to three two-year periods for each firm we are able to use variation in the increase in Chinese imports for different periods to achieve identification that does not rely exclusively on the 
industry cross-section. Specifically, we can estimate

$$
\Delta y_{i, s, t}=\beta \cdot \Delta \text { Competition }_{s, t}+\delta_{s}+\delta_{t}+\epsilon_{i, s, t}
$$

where $\Delta$ denotes differences within-firm, and $\delta_{s}$ are NAICS 4-digit industry dummies that control flexibly for (linear) time-trends. When estimating equation (3) with instrumental variables, we use a standard "shift-share" instrument based on interacting the initial share of Chinese imports in the sector (in 1999) with the total change in Chinese exports to the world. The idea is that periods in which Chinese exports are booming more should also be periods during which Canadian firms in sectors for which China had an initial comparative advantage, should experience greater competition.

Table 8 presents the results from this robustness exercise for our major outcomes, providing both the OLS version of equation (3) without industry fixed effects, IV results without industry fixed effects, and IV results that include the industry fixed effects. The results confirm our earlier findings that surviving firms decrease process innovation and experience some negative effects on revenues, employment and profits (note that while some of the effects are now significantly negative the magnitudes for revenue and employment are virtually identical). This provides some reassurance that our results are not simply driven by a spurious correlation between Chinese import share and pre-existing trends in process innovation across industries.

\section{Conclusions}

Motivated by the recent emergence of China as a major international competitor, we empirically analyzed the implications of this competitive shock for firm dynamics in the Canadian manufacturing sector. Our baseline results for average firms, including small and privately-held companies, are consistent with US studies of large, publicly traded Compustat firms. In particular, we document a strong decrease in process innovations in response to more Chinese competition that contrasts with a more muted response of product innovation. Furthermore, initial heterogeneity in business strategy turns out to be important for understanding the aggregate responses. Our findings indicate that business strategies pursuing differentiation along product space or geographic dimensions leave firms systematically exposed to higher risk. On the one hand, exit likelihoods in response to Chinese competition increase. On the other hand, adverse effects of Chinese competition on profits are attenuated if companies manage to survive. These empirical results add a more nuanced perspective to recent studies of the response of rich country firms to increased competition from emerging markets. Additionally, they suggest that 
adding risk-return trade-offs to models of international trade and innovation will significantly enhance our understanding of firm dynamics. Note that this additional risk margin is directly related to an aggregate competitive shock. This means that it will influence common, non-diversifiable risks and might therefore influence risk pricing. Such a model might therefore link international trade, innovation and asset pricing. This is a topic, that we leave for future research.

\section{References}

Aghion, Philippe and Peter Howitt, "A Model of Growth through Creative Destruction," Econometrica, 1992, 60 (2).

Amiti, Mary and Amit K. Khandelwal, "Import Competition and Quality Upgrading," Review of Economics and Statistics, 2013, 95 (2), 476-490.

Arkolakis, Costas, Arnaud Costinot, Dave Donaldson, and Andrés Rodríguez-Clare, "The Elusive Pro-Competitive Effects of Trade," Working Paper, 2015.

Atkeson, Andrew and Ariel T. Burstein, "Innovation, Firm Dynamics, and International Trade," Journal of Political Economy, 2010, 118 (3), 433-484.

Atkin, David, Azam Chaudhry, Shamyla Chaudry, Amit Khandelwal, and Eric A. Verhoogen, "Organizational Barriers to Technology Adoption: Evidence from Soccer-Ball Producers in Pakistan," Working Paper, 2015.

Autor, David H., David Dorn, and Gordon H. Hanson, "The China Syndrome: Local Labor Market Effects of Import Competition in the United States," American Economic Review, 2013, 103 (6), 2121-2168.

_ , _ , and _ , "The China Shock: Learning from Local Labor Market Adjustment to Large Changes in Trade," Working Paper, 2016.

_ , _ , _, Gary Pisano, and Pian Shu, "Foreign Competition and Domestic Innovation: Evidence from US Patents," Working Paper, 2016.

Bena, Jan and Elena Simintzi, "Labor-Induced Technological Change: Evidence from Doing Business in China," Working Paper, 2015.

Bernard, Andrew B., J. Bradford Jensen, and Peter K. Schott, "Survival of the Best

Fit: Exposure to Low-Wage Countries and the (Uneven) Growth of US Manufacturing Plants," Journal of International Economics, 2006, 68 (1), 219-237.

Bloom, Nicholas, Mirko Draca, and John Van Reenen, "Trade-Induced Technical Change? The Impact of Chinese Imports on Innovation, IT and Productivity," Review of Economic Studies, 2015.

_, Paul M. Romer, Stephen J. Terry, and John Van Reenen, "Trapped Factors and 
China's Impact on Global Growth," Working Paper, 2014.

Boldrin, Michele and David K. Levine, "The Case Against Patents," Journal of Economic Perspectives, 2013, 27 (1), 3-22.

Feenstra, Robert C. and David E. Weinstein, "Globalization, Markups and US Welfare," Working Paper, 2010.

Fernandes, Ana M. and Caroline Paunov, "The Risks of Innovation: Are Innovating Firms Less Likely to Die?," Review of Economics and Statistics, 2015, 97 (3), 638-653.

Grossman, Gene M. and Elhanan Helpman, "Quality Ladders and Product Cycles," Quarterly Journal of Economics, 1991, 106 (2), 557-586.

Holmes, Thomas J. and John J. Stevens, "An Alternative Theory of the Plant Size Distribution, with Geography and Intra- and International Trade," Journal of Political Economy, 2014, 122 (2), 369-421.

Hombert, Johan and Adrien Matray, "Can Innovation Help US Manufacturing Firms Escape Import Competition from China?," Working Paper, 2014.

Khandelwal, Amit K., "The Long and Short (of) Quality Ladders," Review of Economic Studies, 2010, 77 (4), 1450-1476.

Klette, Tor J. and Samuel Kortum, "Innovating Firms and Aggregate Innovation," Journal of Political Economy, 2004, 112 (5), 986-1018.

Melitz, Marc J., "The Impact of Trade on Intra-Industry Reallocations and Aggregate Industry Productivity," Econometrica, 2003, 71 (6), 1695-1725.

- and Gianmarco I. P. Ottaviano, "Market Size, Trade, and Productivity," Review of Economic Studies, 2008, 75 (1), 295-316.

Romer, Paul M., "Endogenous Technological Change," Journal of Political Economy, 1990, $98(5)$.

Sutton, John, Competing in Capabilities: The Globalization Process 2012.

Tucker, Catherine, "Patent Trolls and Technology Diffusion: The Case of Medical Imaging," Working Paper, 2014.

Yang, Mu-Jeung, Lorenz Kueng, and Bryan Hong, "Business Strategy and the Management of Firms," Working Paper, 2015. 


\begin{tabular}{|c|c|c|c|c|c|}
\hline \multirow[b]{2}{*}{ Panel A: Initial levels in 1999} & \multirow[b]{2}{*}{$\mathrm{N}$} & \multicolumn{2}{|c|}{ Weighted } & \multicolumn{2}{|c|}{ Unweighted } \\
\hline & & Mean & S.D. & Mean & S.D. \\
\hline Chinese share of Canadian imports & 106 & & & 0.024 & 0.047 \\
\hline US share of Canadian imports (for comparision) & 106 & & & 0.756 & 0.181 \\
\hline Innovation strategy top priority & 1370 & 0.069 & 0.253 & 0.093 & 0.290 \\
\hline Low-cost strategy top priority & 1370 & 0.181 & 0.385 & 0.215 & 0.411 \\
\hline Medium firms (21-499 employees) & 1370 & 0.260 & 0.439 & 0.511 & 0.500 \\
\hline Large firms (500 plus employees) & 1370 & 0.007 & 0.083 & 0.110 & 0.313 \\
\hline National firms & 1370 & 0.209 & 0.407 & 0.171 & 0.376 \\
\hline Exporters & 1370 & 0.411 & 0.492 & 0.578 & 0.494 \\
\hline \multirow[t]{2}{*}{ Exit by 2005} & 1370 & 0.169 & 0.375 & 0.147 & 0.354 \\
\hline & & \multicolumn{2}{|c|}{ Weighted } & \multicolumn{2}{|c|}{ Unweighted } \\
\hline Panel B: Changes from 1999-2005 & $\mathrm{N}$ & Mean & S.D. & Mean & S.D. \\
\hline Chinese share of Canadian imports & 106 & & & 0.038 & 0.053 \\
\hline Perceived non-US foreign competition & 868 & 0.016 & 1.573 & 0.077 & 1.073 \\
\hline Perceived US competition & 868 & 0.005 & 1.363 & -0.001 & 1.489 \\
\hline Innovation strategy top priority & 868 & 0.077 & 1.073 & -0.014 & 1.082 \\
\hline Low-cost strategy top priority & 868 & 0.202 & 0.995 & 0.202 & 0.939 \\
\hline Cumulative product innovations & 913 & 4.436 & 3.263 & 4.923 & 3.426 \\
\hline Cumulative process innovations & 913 & 3.917 & 3.287 & 4.662 & 3.421 \\
\hline$\%$ change in revenue & 864 & 0.256 & 0.704 & 0.223 & 0.742 \\
\hline$\%$ change in employment & 868 & 0.036 & 0.578 & -0.011 & 0.585 \\
\hline$\%$ change in gross payroll & 868 & 0.275 & 0.654 & 0.193 & 0.630 \\
\hline Change in operating profits/1999 revenue & 864 & 0.142 & 1.039 & 0.200 & 1.413 \\
\hline
\end{tabular}


Table 2: Average effect of Chinese import competition on firm performance and exit, 1999-2005

\begin{tabular}{|c|c|c|c|c|c|c|c|c|}
\hline \multirow[t]{2}{*}{ Dependent variable } & \multicolumn{2}{|c|}{ Revenue } & \multicolumn{2}{|c|}{ Payroll } & \multicolumn{2}{|c|}{ Operating Profit Margin } & \multicolumn{2}{|c|}{ Exit } \\
\hline & (1) & $(2)$ & (3) & (4) & $(5)$ & (6) & (7) & (8) \\
\hline & OLS & IV & OLS & IV & OLS & IV & OLS & IV \\
\hline Chinese share of imports & $\begin{array}{c}0.447 \\
(0.785)\end{array}$ & $\begin{array}{l}-2.386 \\
(1.499)\end{array}$ & $\begin{array}{c}0.841 \\
(1.010)\end{array}$ & $\begin{array}{l}-1.353 \\
(1.272)\end{array}$ & $\begin{array}{l}-0.675 \\
(0.521)\end{array}$ & $\begin{array}{l}-0.725 \\
(0.713)\end{array}$ & $\begin{array}{c}0.529 \\
(0.388)\end{array}$ & $\begin{array}{c}0.842^{* *} \\
(0.354)\end{array}$ \\
\hline Observations & 859 & 859 & 863 & 863 & 859 & 859 & 1,354 & 1,354 \\
\hline Adj R-squared & 0.000 & -0.061 & 0.005 & -0.038 & 0.000 & 0.000 & 0.009 & 0.006 \\
\hline First-stage F-statistic & & 13.81 & & 13.81 & & 13.81 & & 40.43 \\
\hline
\end{tabular}

Notes: The regressions use long difference from 1999 to 2005. The Chinese share of imports increses on average by 5 percentage points (pp) from 1999 to 2005 with a standard deviation of 6.3 pp, strating from 2.9\% in 1999. Columns (1)-(6) are based on the subsample of firms that survive until 2005. Robust standard errors in parentheses are clustered by 4-digit NAICS industry. ${ }^{* \star},{ }^{* \star},{ }^{\star}$ mark significance at the 1,5 , and 10 percent level, respectively. 
Table 3: Average effect of Chinese import competition on strategy, 1999-2005

\begin{tabular}{lccccc}
\hline Dependent variable & \multicolumn{2}{c}{ Innovation strategy } & & \multicolumn{2}{c}{ Low-cost strategy } \\
\cline { 2 - 3 } \cline { 5 - 6 } & $(1)$ & $(2)$ & & $(3)$ & $(4)$ \\
\hline \multirow{2}{*}{ Chinese share of imports } & OLS & IV & & OLS & IV \\
& $\left(0.840^{*}\right.$ & -0.361 & & $-2.235^{* *}$ & -0.211 \\
& & $(1.435)$ & & $(0.909)$ & $(1.287)$ \\
Observations & 863 & 863 & & 863 & 863 \\
Adj R-squared & 0.007 & -0.005 & & 0.018 & 0.002 \\
First-stage F-statistic & & 13.81 & & & 13.81 \\
\hline
\end{tabular}

Notes: Dependent variables are normalized continuous strategy Likert scores on importance of strategy, see text. Robust standard errors in parentheses are clustered by 4-digit NAICS industry. ${ }^{* \star *},{ }^{* *},{ }^{*}$ mark significance at the 1,5 , and 10 percent level, respectively. 
Table 4: Average effect of Chinese import competition on innovation and technology adoption

\begin{tabular}{|c|c|c|c|c|c|c|}
\hline \multirow[t]{2}{*}{ Dependent variable } & \multicolumn{2}{|c|}{ Process Innovation } & \multicolumn{2}{|c|}{ Product Innovation } & \multicolumn{2}{|c|}{ Technology expenditure } \\
\hline & (1) & (2) & (3) & (4) & (7) & (8) \\
\hline & OLS & IV & OLS & IV & OLS & IV \\
\hline Chinese share of imports & $\begin{array}{c}-9.799 * * * \\
(3.230)\end{array}$ & $\begin{array}{c}-12.012 * * * \\
(3.799)\end{array}$ & $\begin{array}{l}-6.121^{*} \\
(3.488)\end{array}$ & $\begin{array}{l}-1.748 \\
(4.288)\end{array}$ & $\begin{array}{l}-0.132 \\
(0.238)\end{array}$ & $\begin{array}{l}-0.211 \\
(0.287)\end{array}$ \\
\hline Observations & 908 & 908 & 908 & 908 & 906 & 906 \\
\hline Adj R-squared & 0.033 & 0.031 & 0.012 & 0.006 & 0.000 & 0.000 \\
\hline First-stage F-statistic & & 14.35 & & 14.35 & & 14.31 \\
\hline
\end{tabular}

Notes: Dependent variables are the cumulative number of innovations over 1999 to 2006, by innovation type and cumulative technology expenditure relative to initial revenues in 1999. Robust standard errors in parentheses are clustered by 4-digit NAICS industry. ${ }^{* *},{ }^{* *},{ }^{*}$ mark significance at the 1,5 , and 10 percent level, respectively. 
Table 5: Heterogeneity in effects of Chinese competition by firm size

\begin{tabular}{|c|c|c|c|c|c|}
\hline Dependent variable & $\begin{array}{l}\text { Exit } \\
(1)\end{array}$ & $\begin{array}{c}\text { Revenue } \\
\text { (2) }\end{array}$ & $\begin{array}{c}\text { Process } \\
\text { Innovation } \\
(3)\end{array}$ & $\begin{array}{c}\text { Cost } \\
\text { strategy } \\
(4)\end{array}$ & $\begin{array}{c}\text { Innovation } \\
\text { strategy } \\
\text { (5) }\end{array}$ \\
\hline Chinese share of imports & $\begin{array}{c}1.126 * * \\
(0.482)\end{array}$ & $\begin{array}{l}-0.717 \\
(1.107)\end{array}$ & $\begin{array}{c}-10.347^{* *} \\
(4.213)\end{array}$ & $\begin{array}{c}-2.382 * * \\
(1.027)\end{array}$ & $\begin{array}{c}0.131 \\
(1.701)\end{array}$ \\
\hline Chinese share of imports * Medium & $\begin{array}{l}-0.826^{*} \\
(0.450)\end{array}$ & $\begin{array}{l}-3.823 \\
(4.254)\end{array}$ & $\begin{array}{l}-6.545 \\
(6.311)\end{array}$ & $\begin{array}{l}5.065^{*} \\
(2.739)\end{array}$ & $\begin{array}{l}-0.985 \\
(3.345)\end{array}$ \\
\hline Chinese share of imports * Large & $\begin{array}{l}-0.676 \\
(0.553)\end{array}$ & $\begin{array}{l}-42.248 \\
(37.663)\end{array}$ & $\begin{array}{c}5.645 \\
(23.111)\end{array}$ & $\begin{array}{c}18.606 * * * \\
(6.793)\end{array}$ & $\begin{array}{l}-6.937 \\
(7.875)\end{array}$ \\
\hline Main effect (firm size) & YES & YES & YES & YES & YES \\
\hline Observations & 1,354 & 859 & 908 & 863 & 863 \\
\hline Adj R-squared & 0.003 & -0.087 & 0.106 & -0.001 & -0.008 \\
\hline
\end{tabular}

Notes: All columns are IV regressions; see text for details. The omitted firm size category is small firms. Robust standard errors in parentheses are clustered by 4-digit NAICS industry. ${ }^{\star \star *},{ }^{\star *},{ }^{*}$ mark significance at the 1, 5, and 10 percent level, respectively. 
Table 6: Heterogeneity in effects of Chinese competition by initial business strategy

\begin{tabular}{|c|c|c|c|c|c|c|}
\hline \multirow[b]{2}{*}{ Dependent variable } & \multicolumn{3}{|c|}{ Innovation strategy } & \multicolumn{3}{|c|}{ Low-cost strategy } \\
\hline & $\begin{array}{l}\text { Exit } \\
(1)\end{array}$ & $\begin{array}{l}\text { Revenue } \\
\text { (2) }\end{array}$ & $\begin{array}{c}\text { Payroll } \\
\text { (3) }\end{array}$ & $\begin{array}{l}\text { Exit } \\
(4)\end{array}$ & $\begin{array}{c}\text { Revenue } \\
\text { (5) }\end{array}$ & $\begin{array}{l}\text { Payroll } \\
(6)\end{array}$ \\
\hline Chinese share of imports & $\begin{array}{c}0.737^{* *} \\
(0.347)\end{array}$ & $\begin{array}{l}-2.437 \\
(1.553)\end{array}$ & $\begin{array}{l}-1.103 \\
(1.278)\end{array}$ & $\begin{array}{l}0.620^{*} \\
(0.323)\end{array}$ & $\begin{array}{c}-3.101^{*} \\
(1.815)\end{array}$ & $\begin{array}{c}-2.181^{*} \\
(1.286)\end{array}$ \\
\hline Chinese share of imports * Innovation strategy & $\begin{array}{c}2.122^{* * *} \\
(0.820)\end{array}$ & $\begin{array}{c}5.757^{* *} \\
(2.368)\end{array}$ & $\begin{array}{l}-1.133 \\
(2.878)\end{array}$ & & & \\
\hline Chinese share of imports * Low-cost strategy & & & & $\begin{array}{c}1.231 \\
(0.835)\end{array}$ & $\begin{array}{c}5.160 * * \\
(2.534)\end{array}$ & $\begin{array}{c}5.984^{* * *} \\
(1.748)\end{array}$ \\
\hline Main effect (business strategy) & YES & YES & YES & YES & YES & YES \\
\hline Observations & 1,354 & 859 & 863 & 1,354 & 859 & 863 \\
\hline Adj R-squared & 0.007 & -0.054 & -0.008 & 0.012 & -0.061 & -0.024 \\
\hline First-stage F-statistic & 18.24 & 6.616 & 6.633 & 13.91 & 5.967 & 6.064 \\
\hline
\end{tabular}

Notes: All columns are IV regressions; see text for details. The omitted category for each regression is firms that do not have the featured strategic priority. Robust standard errors in parentheses are clustered by 4-digit NAICS industry. ${ }^{* \star *},{ }^{\star *}$, * mark significance at the 1, 5, and 10 percent level, respectively. 
Table 7: Heterogeneity in effects of Chinese competition by market scope

\begin{tabular}{lccc} 
Dependent variable & $\begin{array}{c}\text { Exit } \\
(1)\end{array}$ & $\begin{array}{c}\text { Revenue } \\
(2)\end{array}$ & $\begin{array}{c}\text { Payroll } \\
(3)\end{array}$ \\
\hline Chinese share of imports & $1.310^{* *}$ & 0.202 & 0.984 \\
& $(0.575)$ & $(0.960)$ & $(1.336)$ \\
Chinese share of imports * National & -0.912 & -8.785 & -7.077 \\
& $(0.591)$ & $(8.824)$ & $(6.280)$ \\
Chinese share of imports * Exporter & -0.907 & $-2.476^{* * *}$ & $-2.630^{* *}$ \\
& $(0.602)$ & $(0.838)$ & $(1.117)$ \\
& & & \\
Main effect (market scope) & YES & YES & YES \\
Observations & 1,330 & 841 & 845 \\
Adj R-squared & 0.007 & -0.091 & -0.061 \\
First-stage F-statistic & 10.40 & 0.509 & 0.509 \\
\hline
\end{tabular}

Notes: All columns are IV regression; for details see text. The omitted category is firms with local (county or municipality) sales only. Robust standard errors in parentheses are clustered by 4-digit NAICS industry. ${ }^{* * *}$, $* *, *$ mark significance at the 1,5 , and 10 percent level, respectively. 
Table 8: Robustness of effects using short (2-year) differences and industry dummies

\begin{tabular}{|c|c|c|c|c|c|c|c|c|c|c|c|c|}
\hline \multirow[t]{2}{*}{ Dependent variable } & \multicolumn{3}{|c|}{ Process Innovation } & \multicolumn{3}{|c|}{ Revenue } & \multicolumn{3}{|c|}{ Employment } & \multicolumn{3}{|c|}{ Operating Profit Margin } \\
\hline & (1) & (2) & (3) & (4) & (5) & (6) & (7) & (8) & (9) & (10) & (11) & $(12)$ \\
\hline & OLS & IV & IV & OLS & IV & IV & OLS & IV & IV & OLS & IV & IV \\
\hline Chinese share of imports & $\begin{array}{c}-6.251^{* * *} \\
(1.551)\end{array}$ & $\begin{array}{c}-11.628^{* * *} \\
(2.412)\end{array}$ & $\begin{array}{c}-9.574 * * \\
(4.198)\end{array}$ & $\begin{array}{c}0.639 \\
(0.931)\end{array}$ & $\begin{array}{l}-1.950 * \\
(1.044)\end{array}$ & $\begin{array}{l}-2.278 \\
(1.392)\end{array}$ & $\begin{array}{l}-0.418 \\
(0.577)\end{array}$ & $\begin{array}{c}-1.874 * * * \\
(0.711)\end{array}$ & $\begin{array}{c}-2.320 * * \\
(0.911)\end{array}$ & $\begin{array}{l}-0.594 \\
(0.553)\end{array}$ & $\begin{array}{c}-1.297^{* *} \\
(0.656)\end{array}$ & $\begin{array}{l}-3.520^{*} \\
(1.910)\end{array}$ \\
\hline Industry FE & No & No & Yes & No & No & Yes & No & No & Yes & No & No & Yes \\
\hline Observations & 3,424 & 3,424 & 3,424 & 3,348 & 3,348 & 3,348 & 3,356 & 3,356 & 3,356 & 3,345 & 3,345 & 3,345 \\
\hline Adj R-squared & 0.021 & 0.004 & 0.141 & 0.006 & -0.012 & 0.016 & 0.001 & -0.006 & 0.048 & 0.002 & 0.001 & 0.005 \\
\hline First-stage F-statistic & & 27.29 & 50.12 & & 25.37 & 45.10 & & 25.55 & 45.34 & & 25.30 & 45.08 \\
\hline
\end{tabular}

Notes: Because the variables of interest are measured as two-year within-firm differences, the industry dummy is equivalent to an industry linear time-trend. Robust standard errors in parentheses are clustered by 4-digit NAICS industry. ${ }^{\star \star \star},{ }^{\star \star},{ }^{*}$ mark significance at the 1,5 , and 10 percent level, respectively. 
Figure 1 - First Stage of IV

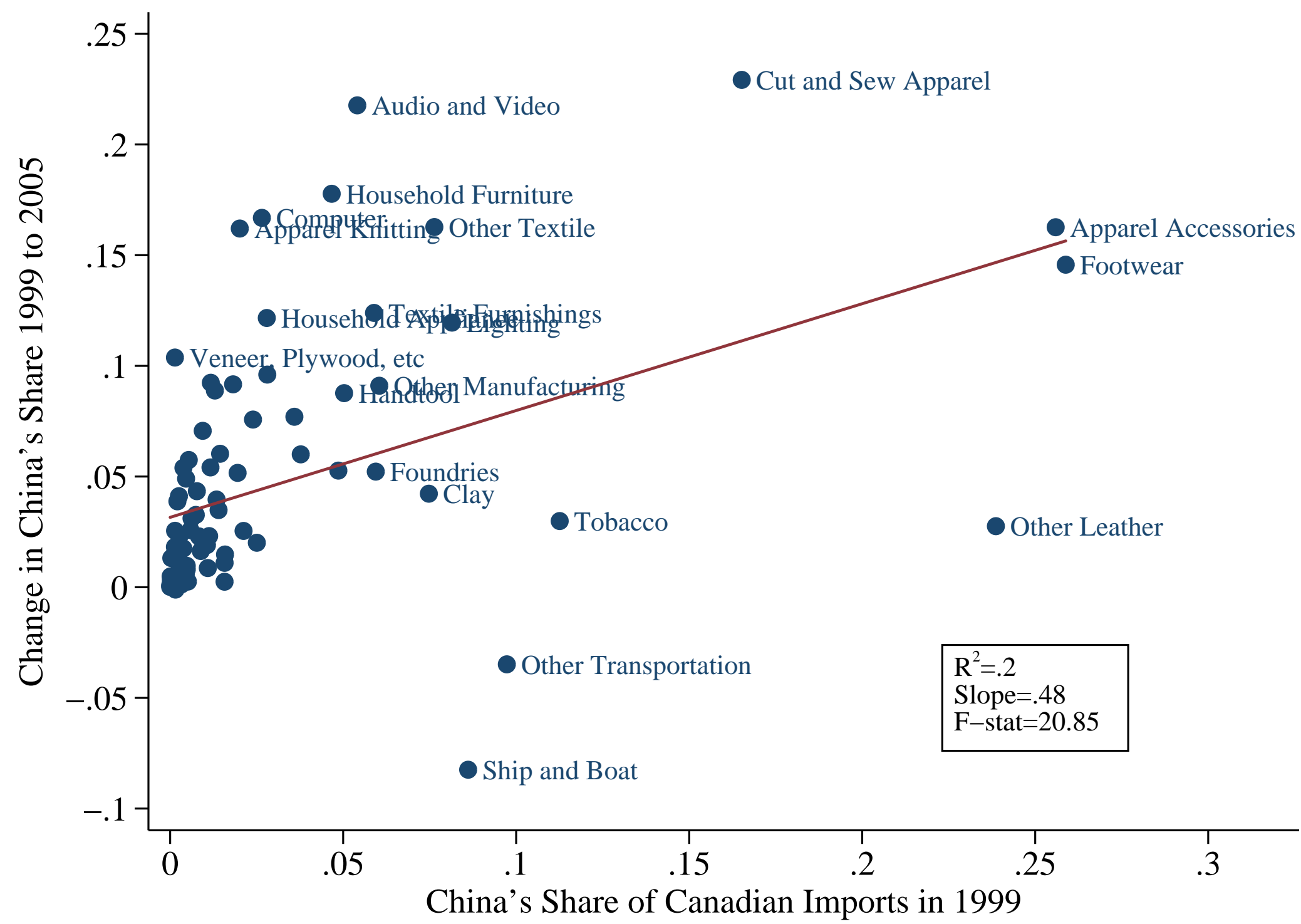




\section{Online Appendix}

\section{A. WES Questionnaire (Workplace and Employee Survey)}

\section{Section G : Business Strategy}

34. Please rate the following factors with respect to their relative importance in your workplace general business strategy.

\begin{tabular}{|c|c|c|}
\hline Jot & Not & $\begin{array}{c}\text { Slightly } \\
\text { important }\end{array}$ \\
\hline
\end{tabular} A. Undertaking research and
development
${ }^{1} \bigcirc$
${ }^{2} \bigcirc$
${ }^{3} \bigcirc$
${ }^{4} \bigcirc$
${ }^{5} \bigcirc \quad{ }^{6} \bigcirc$
B. Developing new products / services

${ }^{1} \bigcirc \quad{ }^{2} \bigcirc \quad{ }^{3} \bigcirc \quad{ }^{4} \bigcirc$

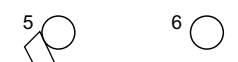
C. Developing new production / operating techniques

${ }^{2} \bigcirc \quad{ }^{3} \bigcirc$
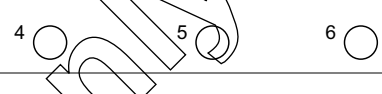
D. Expanding into new geographic markets

${ }^{1} \bigcirc \quad{ }^{2} \bigcirc \quad{ }^{3} \bigcirc$
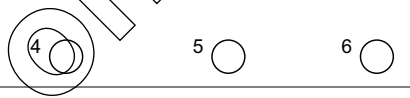
E. Total quality management
${ }^{2} \bigcirc$
${ }^{3} \curvearrowright{ }^{4} \mathrm{O}$
${ }^{5} \bigcirc$
${ }^{6} \bigcirc$ F. Improving product / service
quality
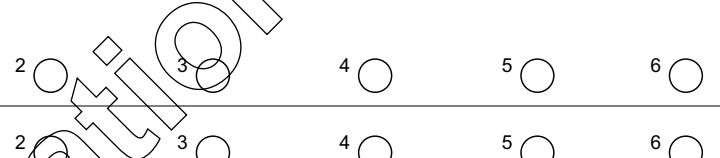
G. Reducing labour costs

${ }^{1} \bigcirc$
$2 y^{3} 0$
${ }^{4} \bigcirc$

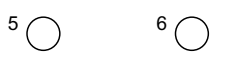
H. Using more part-time, temporary or contract workers
I. Reducing other operating costs
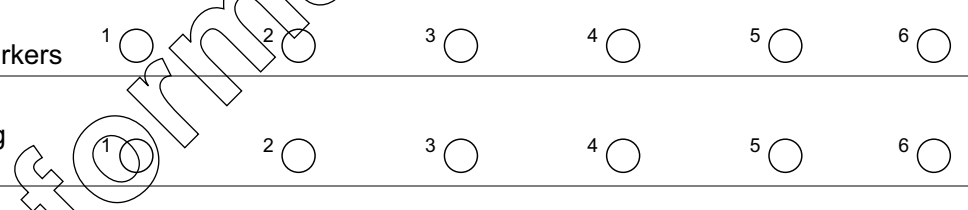
J. Reorganizing the work process

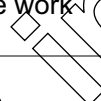
K. Enhancing labour- management cooperation
L. Increasing employees' skills
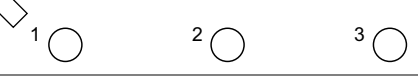
${ }^{4} \bigcirc$
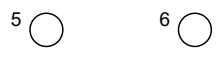 $<$
M. Increasing employees' involvement / participation
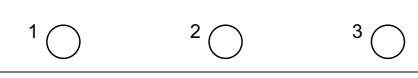
${ }^{4} \bigcirc$
${ }^{5} \bigcirc$

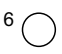
involvement/ participation
N. Improving coordination with customers and suppliers

${ }^{2} \bigcirc \quad{ }^{3} \bigcirc$

${ }^{4} \bigcirc$
${ }^{5} \bigcirc$

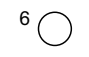

${ }^{1} \bigcirc$

${ }^{2} \bigcirc$
${ }^{3} \bigcirc$
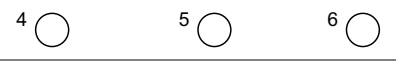

${ }^{1} \bigcirc$

${ }^{2} \bigcirc \quad{ }^{3} \bigcirc$
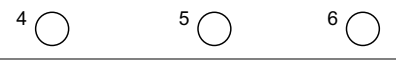
O. Improving measures of performance

${ }^{1} \bigcirc$

${ }^{2} \bigcirc$

${ }^{3} \bigcirc$

${ }^{4} \bigcirc$
${ }^{5} \bigcirc$

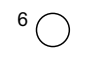




\section{If you reported "non-profit organization" in Question 28, go to Question 40.}

35. Between April 1, 2004 and March 31, 2005, what percentage of your total sales from all products and services were in each of the following market areas?
A. Local market (same municipality or county)
$\%$
B. Rest of Canada
$\%$
C. U.S.A.
$\Delta|+| \%$
D. Rest of the world
Total $(A+B+C+D$ should total $100 \%)$
$100 \%$

36. Do you directly compete with locally, Canadian or internationally-owned firms? (Check all that apply.)

${ }^{1} \bigcirc$ Yes, locally-owned firms

${ }^{2} \bigcirc$ Yes, Canadian-owned enterprises

${ }^{3} \bigcirc$ Yes, American-owned enterprises

${ }^{4} \bigcirc$ Yes, other internationally-owned enterpuses (other than American)

${ }^{5} \bigcirc$ No $\rightarrow$ Go to Question 40

36 (a) To what extent do these finms dffer significant competition to your business?

Significant competition refers to a situation where other firms market products / services similar to yours which could be purchased by your customers.

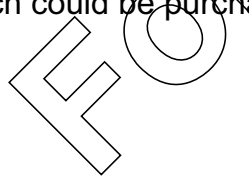

\section{Not} applicable important

Slightly

Very Don't

important Important important Crucial know
A. Locally-owned
${ }^{1} \bigcirc \quad{ }^{2} \bigcirc$
${ }^{3} \bigcirc$
${ }^{4} \bigcirc$
${ }^{5} \bigcirc$

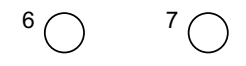
B. Canadian-owned

${ }^{1} \bigcirc \quad{ }^{2} \bigcirc$
${ }^{3} \bigcirc$
${ }^{4} \bigcirc$
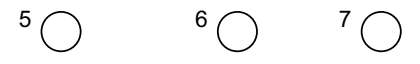
C. American-owned

${ }^{1} \bigcirc$
${ }^{2} \bigcirc$
${ }^{3} \bigcirc$
${ }^{4} \bigcirc$
${ }^{5} \bigcirc$
${ }^{6} \bigcirc \quad{ }^{7} \bigcirc$
D. Other internationally- owned

${ }^{1} \bigcirc$
${ }^{2} \bigcirc$
${ }^{3} \bigcirc$
${ }^{4} \bigcirc$
${ }^{5} \bigcirc$
${ }^{6} \bigcirc$
${ }^{7} \bigcirc$ 
37. Please indicate how many firms (whether based in Canada or not) offer products / services directly competing with yours in your most important market. Your most important market is represented by the highest percentage of your total sales reported in Question 35.

Products directly competing refers to products / services, whether brand name or generic, that compete directly with yours in the same market. In other words, products / services which compete with yours to satisfy the same needs of the same customers.

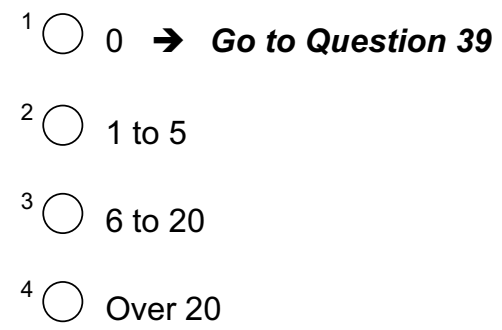

38. Please indicate the general price level of your products / services relative to the price level of your main competitors in your most important market.

${ }^{1} \bigcirc$ Higher

${ }^{2} \bigcirc$ About the same

${ }^{3} \bigcirc$ Lower

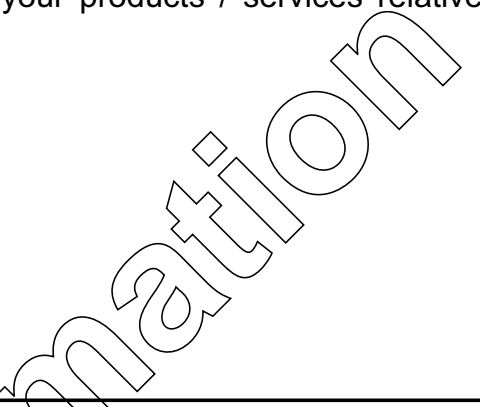

39. Compared to your main competitors, how would you rate your workplace performance between April 1, 2004 and March 31, 2005 in each of the following areas?

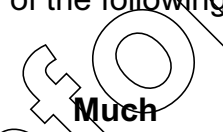
nuen weose

Worse

$\begin{array}{ccc}\begin{array}{c}\text { About the } \\ \text { same }\end{array} \quad \text { Better } & \begin{array}{c}\text { Much } \\ \text { better }\end{array} & \begin{array}{l}\text { Don't } \\ \text { know }\end{array}\end{array}$
A. Productivity

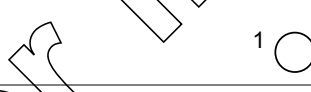
${ }^{2} \bigcirc$
${ }^{3} \bigcirc$

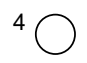
${ }^{5} \bigcirc$
${ }^{6} \bigcirc$
B.

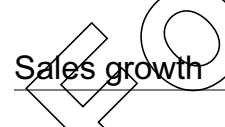
${ }^{2} \bigcirc$
${ }^{3} \bigcirc$
${ }^{4} \bigcirc$
${ }^{5} \bigcirc$
${ }^{6} \bigcirc$
C. Profitability
${ }^{1} \bigcirc$
${ }^{2} \bigcirc$
${ }^{3} \bigcirc$
${ }^{4} \bigcirc$
${ }^{5} \bigcirc$ 


\section{Section H : Innovation}

40. Between April 1, 2004 and March 31, 2005, has this workplace introduced...

Yes

A. new products or services? ${ }^{1}$

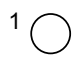

B. improved products or services? ${ }^{2}$

C. new processes? ${ }^{3}$

D. improved processes? ${ }^{4}$

1 New products or services differ significantly in character or intended use from previously produced goods or services.

2 Improved products or services are those whose performance has be significantly enhanced or upgraded.

3 New processes include the adoption of new methods of goods production or service delivery.

4 Improved processes are those whose performance has been significantly enhanced or upgraded.

If you have answered "No" to A, B, C and D, go to Question 43.

41. What was your most important innovation between April 1, 2004 and March 31, 2005? By most important, we mean the one which cost the most to implement.

42. Was this innovation

13 a world first?

${ }^{2} \bigcirc$ a Canadian first?

${ }^{3} \bigcirc$ a first in the local market?

${ }^{4} \bigcirc$ none of the above. 